\title{
DETECTION OF P53 MUTATIONS ON ORAL SQUAMOUS CELL CARCINOMA
}

\author{
Peter Agus \\ Department of Oral and Maxillofacial Surgery Faculty of Dentistry Airlangga University
}

\begin{abstract}
Oral squamous cell carcinoma ( OSCC) is the most common malignant tumor of the oral cavity, and its account for $80-90 \%$ of all malignancies in oral cavity. The aim of this study was to determine the presence of p53 mutations and to associate these mutations with the histopathological type of OSCC such as well differentiated and poorly differentiated. Analitycal observational comparative study by cross sectional design was used. Forty untreated well and poorly differentiated OSCC biopsy sample and normal tissue biopsy material taken from 16 normal patients were analyzed for the presence of mutation in the conserved region of the p53 gene especially in exon 5 by polymerase chain reaction-single strand conformation polymorphism (PCR-SSCP). The results of this study showed that p53 gene mutations were detected in exon $5 ; 11 / 40$ $(27,5 \%)$ with heterozygous mutation $9 / 11(81,8 \%)$. The incidence in exon 5 of p53 gene mutation was significantly accociated with well differentiated $2 / 20(10 \%)$ and poorly differentiated $9 / 20(45 \%)$ $\operatorname{OSCC}(\mathrm{P}=0,013)$. This study concludes that 1) mutation in exon 5 of p53 gene occurred frequently in $\mathrm{OSCC}$; 2) exon 5 of the p 53 gene could be one of the the specific targets for histopathological grade of OSCC; 3)mutation in exon 5 of p53 gene could be important prognostic factor in OSCC. Indonesian Journal of Dentistry 2006; Edisi Khusus KPPIKG XIV:239-242
\end{abstract}

Key words : p53, mutation, OSCC, well differentiated, poorly differentiated.

\section{Introduction}

Oral squamous cell carcinoma ( OSCC) is the most common malignant tumor of the oral cavity, and its account for $80-90 \%$ of all malignancies in oral cavity. Mortality rate remains high is about $5 \%$ in worldwide and $2,4 \%-3,57 \%$ in Indonesia of all cancers death. ${ }^{1,2}$ Until now, the molecular pathogenesis of OSCC is still unclear and caused by the diagnosis is only based on clinicopathological examination. Consequently, the most frequent OSCC cases are found in advanced stage approximately $76,3 \%$ therefore the management of OSCC has not shown satisfactory outcome. ${ }^{2}$

Disruption of the cell cycle as well as regulatory genes component which involved in controling cell cycle is the main factor in the development process of all malignancies. p 53 tumor suppressor gene has an important role in malignancy development process especially in early phase of cell cycle G1-S and loss of function p53 gene is the most common cause of OSCC. ${ }^{3}$ Furthermore, p53 gene has been shown a direct activation and an essential role to control and to regulate cell cycle as well as could induce apoptosis. ${ }^{4}$ Subsequently, inactivation of $\mathrm{p} 53$ gene would be the activity of p53 disrupted results in uncontrolled cell proliferation and if continuously occur therefore could be malignancy in all cancers. ${ }^{4}$

Although the tumor suppressor gene $\mathrm{p} 53$ is the most frequently mutated gene in a wide variety of human cancers, it is not clear whether the p53 gene is also involved in OSCC since few studies have been reported previously on $\mathrm{p} 53$ mutation in OSCC 
and the role of p53 mutation in the etiology of oral cancer has not been rigorously studied in Indonesia. Previous studies have shown a lower incidence of mutation of $p 53$ gene associated with well differentiation squamous cell carcinoma in Japan. However, these studies have been based on an analysis of relatively few cases of oral squamous cell carcinomas (OSCC). In addition, association between the observed pattern or incidence of $p 53$ mutations in OSCC with associated histopathological grade were not explored in Surabaya, Indonesia. In this study, we examined tumor tissues from 40 patients with primary OSCC for mutations in one of the conserved regions of the p53 gene (exon 5) and analyzed the incidence of mutations for association with histopathological grade

The aim of this study was to determine the presence of p53 mutations and to associate these mutations with the histopathological type of OSCC such as well differentiated and poorly differentiated.

\section{Materials and Methods}

Patients, tissue specimens and clinicopathological diagnosis. The Ethical Clearance Committee of Medical Faculty, Airlangga University, Dr Sutomo General Hospital Surabaya, approved this experimental study, In this study, analitycal observational comparative study by cross sectional design was used. The material of observation in this study were 40 untreated patients who clinical diagnosis as suspected oral cancer and histopathological diagnosis from biopsy tissue specimens were reconfirmed from hematoxylineosin stained sections were 20 well differentiation OSCC and 20 poorly differentiation OSCC according to the WHO classification and 16 normal patients who fulfilled the observational requirement. The tumor staging (TNM) was determined according to the 1987 classification of UICC.

For each case, a pair of tumor sample and normal or controlled sample were surgically dissected into small pieces, frozen immediately in liquid nitrogen and stored at $-80^{\circ} \mathrm{C}$. Furthermore, patients were classified into two groups consisted of 40 tumor samples were 20 well differentiated OSCC, 20 poorly differentiated OSCC and 16 normal or controlled sample patients who taken from normal tissue on impacted third molar with surgery indication.

\section{DNA Extraction.}

The DNA was extracted from all tumor and control samples. They were then cut into small pieces $(0,5 \times 0,5 \times 0,5 \mathrm{~cm})$ and placed into eppendorf tubes, washed with PBS solution, added with $700 \mu \mathrm{l}$ of $50 \mathrm{mM}$ Tris $\mathrm{HCl}, \mathrm{pH} 8,100 \mathrm{mM}$ EDTA, $100 \mathrm{mM} \mathrm{NaCl}, 1 \%$ SDS, $50 \mu \mathrm{l}$ of $10-20$ $\mathrm{mg} / \mathrm{ml}$ proteinase- $\mathrm{K}$ and incubated at $55^{\circ} \mathrm{C}$ overnight. DNA extraction in $0,5 \mathrm{ml}$ fenol / CIAA and placed on overhead shaker (Eppendorf mixer 5432) for 2 hours, spin eppendorf for $5 \mathrm{~min}$, shaking on vertical rotator and transfer to a fresh tube. Then, added with $500 \mu \mathrm{l}$ isopropanol / etanol and mix until stringy precipitate form, decant supernatan. Followed by added 500 $\mu \mathrm{H}$ TE buffer and incubated overnight at room temperature. Afterward, eppendorf tube was shaken with hand in order to be well mixed. DNA identification was done using $2 \%$ agarose gel electroforesis and visualized by UV light. DNA concentration test using spectrophotometry. ${ }^{6}$

\section{PCR-SSCP Analysis.}

PCR was performed in $25 \mu \mathrm{l}$ of reaction mixture containing $100-150 \mathrm{ng}$ of genomic DNA, PCR bead / PCR Ready to go, $2 \mu$ LNA sample OSCC, $1 \mu$ primerl exon $5 \mathrm{~A}, 1 \mu \mathrm{l}$ primer 2 exon $5 \mathrm{~A}$, $21 \mu \mathrm{l} \mathrm{dH}_{2} \mathrm{O}$ in eppendorf tube and shaking on vertical rotator (Perkin-Elmer Cetus, Norwalk, CT). We used 2 pairs of primers set to amplify as follows: exon 5A, 5' - TGT TCA CTT GTG CCC TGA CT $-3^{\prime}$ and 5' - AGC AAT CAG TGA GGA ATC AG - 3' for exon 5B; 5'- TTC AAC TCT GTC TCC TTC CT $-3^{\prime}$ and 5'-CAG CCC TGT CGT CTC TCC AG-3'. The PCR for DNA normal sampels are equally prosedure as performed by typical PCR condition. Typical PCR conditions were as follows: $4 \mathrm{~min}$ of denaturation at $94^{\circ} \mathrm{C}$, then 30 cycles at $95^{\circ} \mathrm{C}$ for $4 \mathrm{~min}$, annealing at $55^{\circ} \mathrm{C}$ for $2 \mathrm{~min}$, and extension $72^{\circ} \mathrm{C}$ for $3 \mathrm{~min}$. An elongation step at $72^{\circ} \mathrm{C}$ for $2 \mathrm{~min}$ was added to the final cycle for exons for DNA tumor. PCR conditions for p53 exon $5 \mathrm{~A}$ continued as follows: 1 min of denaturation at $94^{\circ} \mathrm{C}$, then 30 cycles at $94^{\circ} \mathrm{C}$ for $1 \mathrm{~min}, 56^{\circ} \mathrm{C}$ for $1 \mathrm{~min}$, and $72^{\circ} \mathrm{C}$ for $2 \mathrm{~min}$. An elongation step at $72^{\circ} \mathrm{C}$ for $5 \mathrm{~min}$ was added to the final cycle for exons A. The optimum PCR product has shown with 1 band in $2 \%$ agarose gel electroforesis. Then , $5 \mu \mathrm{l}$ exon $5 \mathrm{~A}$ PCR product used by template for p53 exon $5 B$ with added $1 \mu \mathrm{l}$ primer 1 exon $5 B, 1 \mu l$ primer 2 exon $5 B$, PCR bead

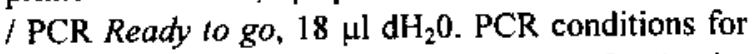
exon $5 \mathrm{~B}$ as follows: denaturation $95^{\circ} \mathrm{C}$ for $4 \mathrm{~min}$, 
annealing $61^{\circ} \mathrm{C}$ for $2 \mathrm{~min}$. Extension $72^{\circ} \mathrm{C}$ for $3 \mathrm{~min}$, 1 cycle. Then, denaturation $94^{\circ} \mathrm{C}$ for $1 \mathrm{~min}$, annealing $62^{\circ} \mathrm{C}$ for $1 \mathrm{~min}$, extension $72^{\circ} \mathrm{C}$ for $2 \mathrm{~min}$, 30 cycles and extra extension $72^{\circ} \mathrm{C}$ for $5 \mathrm{~min}$. The optimum of PCR product has shown with 1 band in $2 \%$ agarose gel electrophoresis compared with band of PNA marker at $300 \mathrm{bp}{ }^{6}$

For SSCP Analysis. $5 \mu \mathrm{l}$ aliquots of the labeled PCR products were mixed with $10 \mu \mathrm{l}$ of formamide loading dye (95\% formamide, $20 \mathrm{mM}$ EDTA $0.05 \%$ bromphenol blue, and $0.05 \%$ xylene cyacoly and were denatured for $10 \mathrm{~min}$ at $95^{\circ} \mathrm{C}$ and chilled on ice until loading for 5-10 min. A $15-\mu 1$ aliquen of each sample was loaded onto a $12 \%$ polyacrylamide gel with or without containing $5 \%$ glycerol and electrophoresis was performed at $150^{\circ} \mathrm{C}$ constant volume for $5 \mathrm{~h}$ at room temperature. Followed by silver staining with the following procedure: fîxer solution (7,5\% acetic acid) for 30 min and washed $(3 \mathrm{x})$ using dionized water $\left(\mathrm{dH}_{2} \mathrm{O}\right)$ for $5 \mathrm{~min}$. Then added witl $100 \mathrm{ml}$ silver nitrate solution ( $1,5 \mathrm{~g} / 1 \mathrm{AgNO}_{3}, 0.056 \%$ formaldehyde) for $45 \mathrm{~min}$ and rinsed with dionized water for 15 seconds. Furthermore, image development was done with developer solution $\left(30 \mathrm{~g} / \mathrm{L} \quad \mathrm{Na}_{2} \mathrm{CO}_{3}, 0,0056\right.$ formaldehyde, $2 \mathrm{mg} / 1$ sodium thiosulfate) for $2-5 \mathrm{~min}$ and stop solution with fixer solution $(7,5 \%$ acetic acid. used at $4^{\circ} \mathrm{C}$ ) for $5 \mathrm{~min} .^{6}$

\section{Statistical Amalysis.}

All statistical andyses were performed using SPSS program version 11. The Contigency coefficient test were used for statistical analysis of the association between the incidence of p53 exon 5 and histopathogical grade such as. well differentiation and poorly differentiation.

\section{Results}

Single-stranded conformation polymorphism (SSCP) analysis was used to analyze all tumor and control samples for mutations within exon 5 of the p53 gene, which is one of the regions most frequently affected by mutations in human tumors. Cases displaying an altered electrophoretic mobility were re-amplified in another separate reaction

Eleven of the 40 tumors $(27,5 \%)$ exhibited 2 bands (homozygote) or extra bands ( 3 or 4 band; heterozygote ) in the SSCP analysis of p53 exon 5 in unsimilar position with 2 band of DNA control, indicating mutations ( + ; or score 1 ). Twenty nine of 40 tumors $(72,5 \%)$ of p53 exon 5 showed 2 band with similar position to 2 band of DNA controlled indicating absence of mutation ( - ; or score 0 ). Two of 11 ( $18,2 \%)$ of p53 exon 5 showed homozygote mutation and heterozygote mutation 9/11 (81,\%), Tabel I,Fig 1 .

Table I. Incidence mutations of the $p 53$ gene exon 5

\begin{tabular}{|c|c|c|c|c|c|c|c|}
\hline \multirow{2}{*}{\multicolumn{2}{|c|}{ oscc }} & \multicolumn{6}{|c|}{ Incidence Mutations (\%) } \\
\hline & & $\begin{array}{l}\text { Yuta } \\
\text { tion } \\
i+1\end{array}$ & $\begin{array}{l}\text { No } \\
\text { Mlutati } \\
\text { on } \\
(-)\end{array}$ & Total & $\begin{array}{l}\text { Homo } \\
\text { zigotc }\end{array}$ & $\begin{array}{l}\text { Hetero } \\
\text { zigote }\end{array}$ & $\begin{array}{l}\text { To } \\
\text { tall }\end{array}$ \\
\hline$p 53$ & Exon & $\begin{array}{c}11 \\
(27,5 \%)\end{array}$ & $\begin{array}{c}29 \\
(72,5 \%)\end{array}$ & 40 & $\begin{array}{c}2 \\
(\lfloor \$, 2 \%\end{array}$ & $\begin{array}{c}9 \\
(81,8 \%)\end{array}$ & $\pi$ \\
\hline
\end{tabular}

Figure 1. PCR-SSCP analysis of the p53 gene exon $\$$ by silver staining. Four band with shifted mobility was seen in tumor No 31, 34,35, 40 showed heterozygote mutation and homozygote mutation was seen in tumor No 36 .

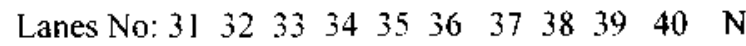

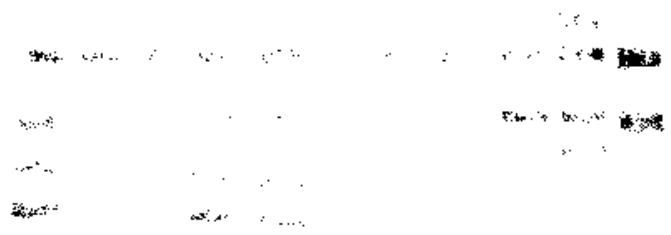

Notes : $N=$ IJNA control

The incidence of p53 exon $5(27,5 \%)$ was significantly associated with well differentiated and poorly differentiated patients $(p=0,013)$, Tabel 2 .

Tabel 2. The result of statistical test of the association betwecn incidence of p53 exon 5 and histopatho-logical feature (well differentiation and poorly differentiation) of OSCC.

\begin{tabular}{|c|c|c|c|c|c|c|}
\hline & Vuriable & & Test ${ }^{\circ}$ & $\mathrm{dr}$ & Value & $\begin{array}{l}\mathbf{P} \\
\text { (sog) }\end{array}$ \\
\hline \multirow{2}{*}{$\begin{array}{l}\mathrm{HPA} \\
\mathrm{OSCC}\end{array}$} & Well Diff. & \multirow{2}{*}{$\begin{array}{c}\text { Mutation } \\
F^{53} \\
\text { exnn } 5\end{array}$} & \multirow[t]{2}{*}{$\begin{array}{l}\text { Contigersy } \\
\text { coeftricient }\end{array}$} & \multirow[t]{2}{*}{ I } & \multirow[t]{2}{*}{0.365} & \multirow[t]{2}{*}{0,013} \\
\hline & d'oorly Diff & & & & & \\
\hline
\end{tabular}

Notes : well diff $=$ well differentiation, poorly diff $=$ poorly differentiation

\section{Discussion}

Mutation at $p 53$ has been demonstrated in over $50 \%$ of all human cancers. The much higher 
mutation frequency of p53 exon 5 of OSCC detected in Sri Lanka $70 \%(7 / 10)^{7}$, while different from the finding of my research since the same screening protocol was able to detect frequent $\mathrm{p} 53$ mutations in other kinds and location tumor samples. Therefore, these studies have been based on an analysis of relatively few cases of oral squamous cell carcinomas (OSCC). In addition, associations between the incidence of p53 mutations exon 5 in the conserved region especially exon 5 with histopathological grade such well differentiated and poorly differentiated OSCC were not explored in Indonesia. In this study, mutation in $\mathrm{p} 53$ exon 5 has shown $27,5 \%(11 / 40)$ which different from mutation the incidence of p53 exon 5 in Sri Lanka. ${ }^{7}$ These discrepancies may be partly a result of the inclusion of patients from different geographic areas and differences in the technique used to analyze the mutations. $^{7}$

Absence of mutation p53 exon 5 was found $72,5 \%(9 / 40)$. It is speculated that other genetic alterations which may be either equivalent to inactivation of the normal function of the 553 protein or involved in other carcinogenic pathways or may caused by the product of the $M D M 2$ gene is known to bind to p53 protein and inhibit its ability to activate transcription causing loss of the normal function of the $p 53$ gene. Alternatively, The E6 proteins of HPV types 16 and 18 are considered to have transforming ability by binding to the p53 protein and inhibiting its function through a ubiquitin-dependent proteolysis system could be loss of function of the p53 gene. ${ }^{8}$

Interestingly, high mutation of heterozygote $81,8 \%$ (9/11) p 53 exon 5 can also caused allelic loss of p53 and abnormally amplified centrosomes that profoundly affect mitotic fidelity and resulted in unequal segregation of chromosomes and enhanced genetic instability.

The assosiation between incidence mutation of p53 (exon 5) with well and poorly differentiated OSCC were statistically significant $(\mathrm{P}=0,013)$. These findings suggested that there is a very high degree of genetic instability in these tumors and the p53 exon 5 gene is a primary targeted of OSCC and played a critical role of this tumor suppressor gene in the multistep carcinogenesis process for OSCC. Hence, it can be concluded that mutation in exon 5 of $p 53$ gene occurred frequently in OSCC and could be one of the the specific targeted on histopathological grade of OSCC as well as may could be important prognostic factor in $\mathrm{OSCC}{ }^{8}$ 10 .

\section{Acknowledgments}

I would like to thanks to Drh. Widya Asmara SU, PhD (Head of Genetic Engineering Laboratory of Gajah Mada University, Yogyakarta) for critical discussion and advice. I also thanks to Dr Wayan T Artama for discussion and technical assistance especially for looking for the Primer Set of p53 exon 5 in Germany.

\section{References}

1. WHO. World Health Organization Warns of Growing "Crisis Report Conquering Suffering "Facts from The World Health Report. Geneve: WHO, 1997: 1-5.

2. Ramli M. Problematik Bedah pada Kanker Rongga Mulut Surabaya: Pertemuan Ilmiah Tahunan, PERABOL IX, 1995:1-17.

3. Yeudal WA, Yakus J, Ensley JF. Robbins KC, 1997. Functional Characterization of P53 Molecules in Human Squamous Cell Carcinoma of The Head And Neck. Mol Carc 1997;18:89-96.

4. Somasundaram K, El-Deiry WS. Tumor Supressor p53: Regulation and Function. Frontiers in Bioscience 2000; 1:424-37.

5. Tsurusako SI, Tanaka H. HayashiY, Tohnai I, Ueda $\mathrm{M}$, Ishizaki $\mathrm{K}$. Low Incidence of p53 Mutations in Well-Differentiated Tongue Squamous Cell Carcinoma in Japan. Jap J Clin Oncol 2000; 32:32731

6. Sambrook J, Fritsch EF, Maniatis T, 1989. Molecular Cloning. A Laboratory Manual. 2 id Ed. New York: Cold Spring Laboratory Press, 1989:6.4.-6.60,14.214.35 .

7. Chiba I, Muthumaia M, Yamazaki Y, Uz Zaman A, lizuka T, Amemiya A, Shibata T, Kashiwazaki H. Sugiura C, Fukuda H,1999.Characteristics of Mutations in The p53 Gene of Oral Squarnous-cel! Carcinomas Aassociated with Betel-quid Chewing in Sri Lanka, Int J Cancer 1999; 77(6): 839-42.

8. Tsurusako SI, Tanaka H, Hayashi $\mathbf{H}$, Tohnai I, Ueda M and Ishizaki K. 2002. Low Incidence of p53 Mutations in Well-differentiated Tongue Squamous Cell Carcinoma in Japan, Jap J Clin Oncol 2002; 32 :32731 .

9. Hu N, Huang J, Buck MRE, Tang ZZ, Roth MJ, Wang C, Dawsey SM, Li Guang, Li WJ, Wang QH, Han XY, Ding T, Giffen C, Goldstein AM, Taylor $P R$. Frequent inactivation of the TP53 Gene in Esophageal Squamous Cell Carcinoma from A HighRisk Population in China. Clin Cancer Res 2001; 7:883-91. 